\title{
Examination Of Customer Interest In The Use Of The Mandiri Syariah Mobile Application At PT. Bank Syariah Mandiri Bekasi Branch Office
}

\author{
Akira Bintang Fitra ${ }^{1}$, Arief Suharko ${ }^{2}$, Sugina ${ }^{3}$, Fauzan Manafil Albar ${ }^{4}$, Dwi Apriliasari ${ }^{5}$ \\ Faculty of Economics and Business, 2,3 , Faculty of Information System ${ }^{4,5}$ \\ Bakrie University ${ }^{1,2}$, University of Raharja ${ }^{3,4,5}$ \\ Kawasan Rasuna Epicentrum, Jl. H. R. Rasuna Said No.2, RT.2/RW.5, Karet, Kecamatan \\ Setiabudi, Kuningan, Daerah Khusus Ibukota Jakarta 129401,2 \\ Modern, Jl. Jenderal Sudirman No.40, RT.002/RW.006, Cikokol, Kec. Tangerang, Kota \\ Tangerang, Banten 151173,4,5 \\ Indonesia \\ e-mail: admisi@bakrie.ac.id, arief.suharko@bakrie.ac.id, sugina@raharja.info, \\ fauzan.manafi@@raharja.info, dwi.apriliasari@raharja.info
}

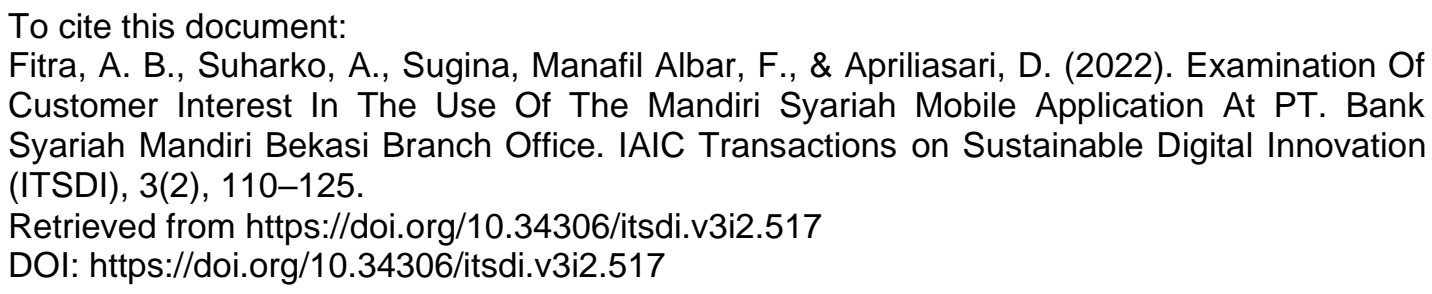
Customer Interest In The Use Of The Mandiri Syariah Mobile Application At PT. Bank Syariah Mandiri Bekasi Branch Office. IAIC Transactions on Sustainable Digital Innovation (ITSDI), 3(2), 110-125.

Retrieved from https://doi.org/10.34306/itsdi.v3i2.517

DOI: https://doi.org/10.34306/itsdi.v3i2.517

\begin{abstract}
We inspect client premium in the utilization of the Mandiri Syariah Mobile application as a type of improvement in the computerized world at one of the Islamic banks in Indonesia. The reason for this review was to decide the impact of control (age, sex, and experience) on the connection between free factors (execution assumptions, exertion, impact of social beliefs, assistance conditions, decadent inspiration, value esteems, and propensities) on the reliant variable (conduct expectations and conduct). utilization conduct) which alludes to the Unified Theory Acceptance and Use of Technology (UTAUT) II model. The technique is a quantitative methodology with an informative examination plan that intends to clarify the factors to be considered and the impact between one variable and another. Social conditions, assistance conditions, indulgent inspiration, value esteems, propensities with conduct expectation factors. Given the consequences of the examination, execution assumptions have the most significant relationship, precisely $43.2 \%$ on social goals. Subsequently, this review proposes that before expanding the connection between social aims to utilize conduct, PT Bank Syariah Mandiri needs to reinforce the impact of the seven factors on social goals.
\end{abstract}

Keywords: Unified Theory of Acceptance and Use of Technology (UTAUT) II Mandiri Syariah Mobile, PT Bank Syariah Mandiri Bekasi Branch.

\section{Introduction}

The origins of the development of the digital economy can be seen based on developments originating from the economic world[1-4]. This development can be seen from the use of internet media and technology as a form of communication, collaboration and also 
cooperation between a company and another company or between one individual and another individual. This form of collaboration, communication and cooperation can bring a profit or profit in an economic activity[4].

The forms of collaboration, communication and cooperation in the development of this media can bring a profit or profit in an economic activity[5].

These economic activities cover various business areas, such as the transportation business, the freight forwarding service business, as well as the banking service business. One example in our daily lives is the process of financial transactions that we do using banking products. A machine or technological tool that is often used in carrying out payment activities is a form of development in the world of technology. Automatic Teller Machine (ATM), mobile banking, Short Message Service (SMS) banking, internet banking and SMS Notifications are some examples of banking service products that utilize technology for their operational activities which we can call "Digital banking" (Financial Services Authority, 2012).

In the development of this digital world era, services in the banking world have undergone changes. In Indonesia, branchless banking services are regulated in the Financial Services Authority Regulation (POJK) number 12/POJK.03/2018. The regulation regulates banking companies in terms of ownership of digital banking products and also safeguards customer data along with transactions made by customers[6].

The Global Community for Mobile Content \& Commerce[7], (2015) describes statistical data for the number of mobile content \& commerce users in Indonesia in 2014 which increased by $9 \%$ from 2012 and $13 \%$ higher than the world average. This finding is supported by the results of their research based on interest in mobile content. The findings can be seen in Figure 1.01 below.

\section{GROWTH IN INDONESIAN MOBILE BANKING BUOYS THE GLOBAL MARKET}

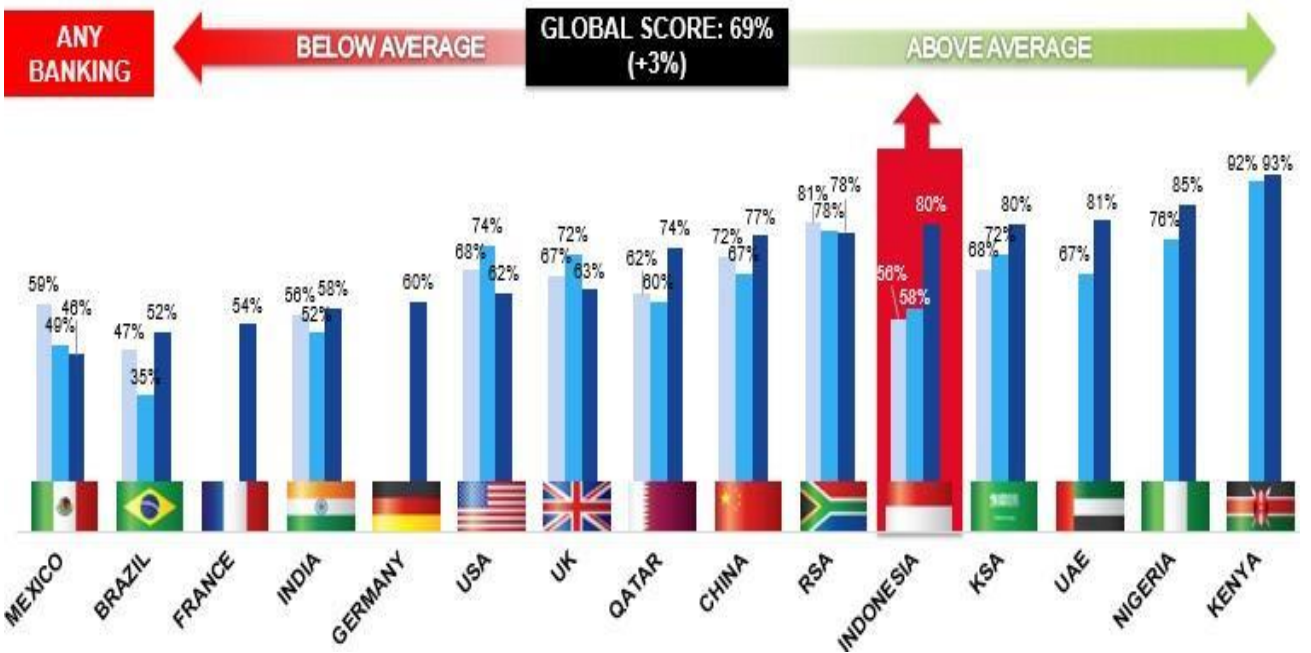

Figure 1. Growth Percentage of Mobile Banking users in Indonesia and several other countries

(Source: The Global Community for Mobile Content \& Commerce, 2015)

Based on Figure 1. above, it can be explained that the results of research in 2015 conducted by The Global Community for Mobile Content \& Commerce, it can be seen that mobile banking users have increased very sharply, it can be seen that mobile banking users in Indonesia in 2012 were $56 \%$, then in 2013 as much as 58\% and in 2014 as much as $80 \%$. Based on the data above, it can be seen that the interest in the use of mobile banking 
applications has increased very sharply and mobile banking applications are applications of interest.

In Indonesia, banks are divided into two types, namely conventional banks and Islamic banks. One of the existing Islamic banking industries is Bank Syariah Mandiri. Bank Syariah Mandiri was established on October 25, 1999. With the majority of shares controlled by one of the State-Owned Enterprises (BUMN), namely PT. Bank Mandiri (Persero) Tbk. One form that the company has taken in order to increase competitiveness is by presenting a new mobile banking named Mandiri Syariah Mobile. Mandiri Syariah Mobile has a variety of new features and services that did not exist in the old form of mobile banking PT. Mandiri Syariah Bank.

Based on Google Play Store data, there are already more than 500,000 downloads of the Mandiri Syariah Mobile application (Google LLC, 2019). The number of downloads of this application is not enough to prove that customers have a high interest in the Mandiri Syariah Mobile application when compared to 743 branch offices under the auspices of 8 regional offices and 7.99 million accounts that have been opened and spread throughout Indonesia for their customers.

One of the branch offices owned by PT Bank Syariah Mandiri is the Bekasi Branch Office (KC) which is active and ranked in the top 10 in the acquisition of fee-based income-digital banking from 28 main branches in Regional Office 3 Jakarta in 2017. This rating proves that this lack of interest can be proven by the comparison of active users and inactive users of the Mandiri Syariah Mobile application which has a ratio of 1: 4 which means that out of 4 accounts registered every day, only 1 active account uses the application. seen in Figure 2 below.

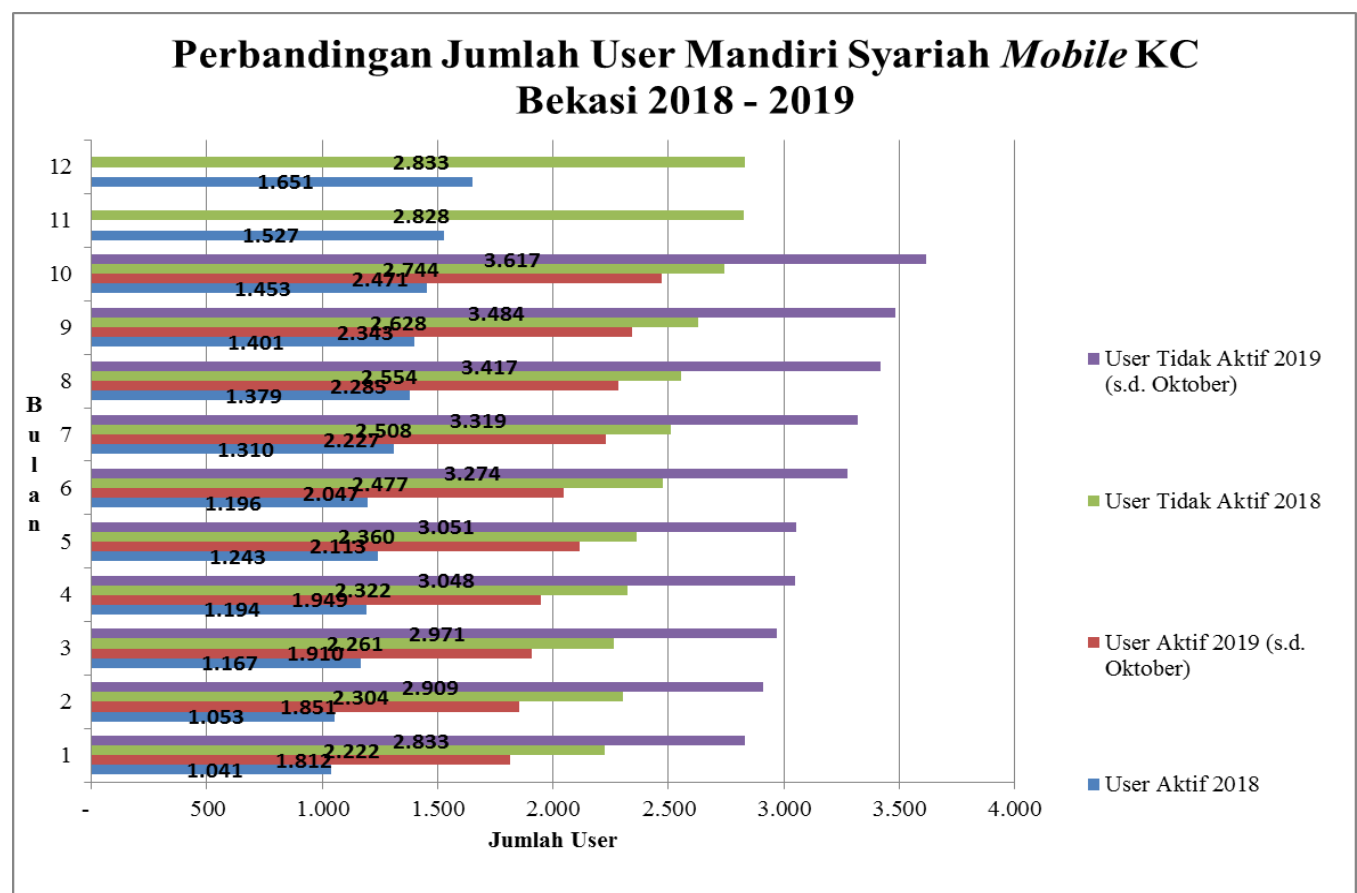

Figure 2. Comparison of the Number of Mandiri Syariah Mobile KC Bekasi Users in 20182019

(Source: Internal Data of PT. Bank Syariah Mandiri Bekasi Branch Office)

Based on Figure 2 above, we can see that in December 2018, there were 4,484 accounts registered with the Mandiri Syariah Mobile application, but of the total, only 1,651 accounts were actively using the application. A total of 2,833 accounts were recorded as inactive when using the Mandiri Syariah Mobile application. The same thing happened in 2019, based on the picture above, it can be seen that there were 6,088 accounts registered with the application, but only 2,471 active accounts were used. A total of 3,617 registered accounts are not active using the Mandiri Syariah Mobile application. Based on the data from Figure 1.02 above, it can 
be concluded that there is low interest in using the Mandiri Syariah Mobile application by KC Bekasi customers.

Based on these problems, PT. Bank Syariah Mandiri can conduct a survey of interests and also use the financial-based applications that they launch. This measurement is intended to find out what factors influence customer interest in using the application, what can be done to develop customer interest in using the application, and so on. Furthermore, in terms of these problems, researchers want to know and want to measure interest in using the Mandiri Syariah Mobile Application. Researchers measure this interest using a theory derived from Venkatesh, et al (2012) known as the Unified Theory of Acceptance and Use of Technology (UTAUT 2) Model[8-10].

The model has 3 independent variables (hedonic motivation, price value, and habit) which are added with performance expectancy, effort expectancy, social influence, facilitating conditions derived from the UTAUT model version 1. The seven variables will be examined on customers of PT. Bank Syariah Mandiri Bekasi Branch Office and associated with the dependent variable, namely behavioral intention. The seven variables will also be associated with age, gender, and experience as variables that can moderate or influence or not on the relationship.

The use of the UTAUT 2 Model in this study, can help PT Bank Syariah Mandiri to predict the development of its technology so that it can be accepted and used by its customers. So that PT. Bank Syariah Mandiri can also seize market share from other Islamic banks, even from conventional banks. Based on the description of the background above and also the phenomena that occur at Bank Syariah Mandiri Bekasi Branch Office, researchers want to know more about the analysis of customer interest in the use of the Mandiri Syariah Mobile application at Bank Syariah Mandiri KC Bekasi.

1. Does the performance expectancy factor moderated by age and gender affect customer interest in using the Mandiri Syariah Mobile application at Bank Syariah Mandiri KC Bekasi?

2. Does the effort expectancy factor moderated by age, gender and experience affect customer interest in using the Mandiri Syariah Mobile application at Bank Syariah Mandiri KC Bekasi?

3. Does the facilitating condition factor moderated by age, gender and experience affect customer interest in using the Mandiri Syariah Mobile application at Bank Syariah Mandiri KC Bekasi?

The purpose of this study was to determine customer interest in the use of the Mandiri Syariah Mobile application at Bank Syariah Mandiri KC Bekasi using the Unified Theory of Acceptance and Use Of Technology (UTAUT) model. digitalization and knowledge of current customer needs so that developments can be carried out that exceed customer expectations. PT Bank Syariah Mandiri has more competitive advantages in the eyes of the community.

\section{Study Literature}

Based on the background that has been described by the researcher in Chapter I, the researcher looks for and reads several references related to the research that will be carried out by the researcher. Acceptance and use of a technology can be measured using the UTAUT Model 2 which focuses more on the use of a technology by customers. UTAUT 2 adds 3 (three) constructs from the first model, namely (habit, hedonic motivation, and price value) on the use and acceptance of information technology. Table 1 shows some of the reading material used by the researcher with the suitability of the model used by the researcher, namely the UTAUT Model 2. This model is used for customer acceptance and also the use of technology. The use is based on several constructs, namely performance expectancy, effort expectancy, social influence, facilitating conditions, hedonic motivation, price value, and habit.

The following are ten previous studies that serve as a reference for this research: 


\begin{tabular}{|c|c|c|c|c|}
\hline No & Author Name, Year & Title & Variable & Conclusion \\
\hline 1 & Karanasios, S. (2018) & $\begin{array}{l}\text { Toward a unified } \\
\text { view of technology } \\
\text { and activity: The } \\
\text { contribution of } \\
\text { activity theory to } \\
\text { information } \\
\text { systems research. } \\
{[11]}\end{array}$ & $\begin{array}{l}\text { Performance } \\
\text { Expectancy (PE), } \\
\text { Effort Expectancy } \\
\text { (EE), Social } \\
\text { Influence (SI), } \\
\text { Facilitating } \\
\text { Condition (FE), } \\
\text { Behavioral } \\
\text { Intention (BI), Use } \\
\text { Behavior, age, } \\
\text { experience, } \\
\text { gender, usage }\end{array}$ & $\begin{array}{l}\text { Based on the research } \\
\text { conducted, the results } \\
\text { obtained that: } \\
\text { PE has a positive and } \\
\text { stronger perceived } \\
\text { relationship with men and } \\
\text { young workers on BI } \\
\text { EE has a positive and } \\
\text { stronger perceived } \\
\text { relationship with women as } \\
\text { well as older workers and } \\
\text { those who have less } \\
\text { experience with BI } \\
\text { SI has a positive and } \\
\text { stronger relationship with } \\
\text { women with lower } \\
\text { experiences of BI } \\
\text { Facilitating conditions have a } \\
\text { positive relationship with a } \\
\text { stronger effect on older } \\
\text { workers with higher } \\
\text { experience of usage. }\end{array}$ \\
\hline 2 & $\begin{array}{l}\text { Visvanath Venkatesh, } \\
\text { James Y.L } \\
\text { Thong, Xin Xu; } 2017\end{array}$ & $\begin{array}{l}\text { Consumer } \\
\text { Acceptance and } \\
\text { Use of Information } \\
\text { Technology: } \\
\text { Extending } \\
\text { The Unified Theory } \\
\text { of Acceptance and } \\
\text { Use of Technology } \\
{[12]}\end{array}$ & \begin{tabular}{|l|} 
Performance \\
Expectancy (PE), \\
Effort Expectancy \\
(EE), Social \\
Influence \\
(SI), Facilitating \\
Conditions (FC), \\
Hedonic Motivation \\
$($ HM), Price Value \\
$(P V)$, Habit, Age, \\
Gender, \\
Experience
\end{tabular} & $\begin{array}{l}\text { Based on the research } \\
\text { conducted, the results } \\
\text { obtained that: } \\
\text { a. HM has a strong influence } \\
\text { on younger men with less } \\
\text { experience of } \mathrm{BI} \\
\mathrm{PV} \text { has a positive effect on } \\
\text { older women. } \\
\text { Habit has a strong influence } \\
\text { on older men with more } \\
\text { experience. }\end{array}$ \\
\hline
\end{tabular}




\begin{tabular}{|c|c|c|c|c|}
\hline 3 & $\begin{array}{l}\text { Indrawati, Dianty } \\
\text { Anggraini Putri; } 2018\end{array}$ & $\begin{array}{l}\text { Analyzing Factors } \\
\text { Influencing } \\
\text { Continuance } \\
\text { Intention of E- } \\
\text { Payment Adoption } \\
\text { Using Modified } \\
\text { UTAUT } 2 \text { Model (A } \\
\text { Case Study of Go- } \\
\text { Pay from } \\
\text { Indonesia) [13] }\end{array}$ & $\begin{array}{l}\text { Habit, Trust, Social } \\
\text { Influence (SI), } \\
\text { Price Saving } \\
\text { Orientation, } \\
\text { Hedonic Motivation } \\
\text { (HM), dan } \\
\text { Performance } \\
\text { Expectancy (PE) }\end{array}$ & $\begin{array}{l}\text { Based on the research } \\
\text { conducted, they can be } \\
\text { sorted from a large impact on } \\
\text { continuance intention to a } \\
\text { small impact, namely: Habit, } \\
\text { Trust, Social Influence (SI), } \\
\text { Price Saving Orientation, } \\
\text { Hedonic Motivation, and } \\
\text { Performance Expectancy. }\end{array}$ \\
\hline 4 & $\begin{array}{l}\text { Gupta, A., Dogra, N., } \\
\text { \& George, B. } 2018 .\end{array}$ & $\begin{array}{l}\text { UTAUT and } \\
\text { UTAUT 2; } \\
\text { A Review and } \\
\text { Agenda for Future } \\
\text { Research [14]. }\end{array}$ & \begin{tabular}{|l|} 
Performance \\
Expectancy (PE), \\
Effort \\
Expectancy(EE), \\
Social Influence \\
(SI), Facilitating \\
Condition (FC), \\
Price Value (PV), \\
Behavioral \\
Intention (BI), \\
Hedonic Motivation \\
$($ HM), Habit
\end{tabular} & $\begin{array}{l}\text { Based on his research, } \\
\text { UTAUT } 2 \text { is more able to } \\
\text { explain and contribute to } \\
\text { future contributions than } \\
\text { UTAUT. }\end{array}$ \\
\hline 5 & $\begin{array}{l}\text { Ahmad Nurul Fajar, } \\
\text { Frits Septian Johanes, } \\
\text { Abba Suganda } \\
\text { Girsang, Gunawan } \\
\text { Wang; (2018) }\end{array}$ & $\begin{array}{l}\text { Evaluation of the } \\
\text { Used of Visual } \\
\text { Electronic Banking } \\
\text { System Application } \\
\text { using UTAUT } 2 \text { in } \\
\text { Bank Central Asia } \\
\text { Corporation [15]. }\end{array}$ & \begin{tabular}{|l|} 
Facilitating \\
Conditions (FC), \\
Social Influence \\
(SI), Effort \\
Expectancy (EE), \\
Habit, Hedonic \\
Motivation (HM), \\
Use Behavior \\
(UB), Performance \\
Expectancy (PE), \\
Effort Expectancy \\
(EE)
\end{tabular} & $\begin{array}{l}\text { Based on research } \\
\text { conducted by FC, PE, SI, HM } \\
\text { have a positive relationship } \\
\text { with } \mathrm{BI} \text { (ordered by the } \\
\text { largest to the smallest } \\
\text { relationship). Meanwhile, EE } \\
\text { and habit have a negative } \\
\text { relationship with BI. BI has a } \\
\text { positive relationship with UB. }\end{array}$ \\
\hline 6 & $\begin{array}{l}\text { Dwivedi, Y. K., Rana, } \\
\text { N. P., Tamilmani, K., } \\
\text { \& Raman, R. (2020) }\end{array}$ & $\begin{array}{l}\text { A meta-analysis } \\
\text { based modified } \\
\text { unified theory of } \\
\text { acceptance and } \\
\text { use of technology } \\
\text { (meta-UTAUT): a } \\
\text { review of emerging } \\
\text { literature. Current } \\
\text { opinion in } \\
\text { psychology, } 36, \\
\text { 13-18. [16]. }\end{array}$ & 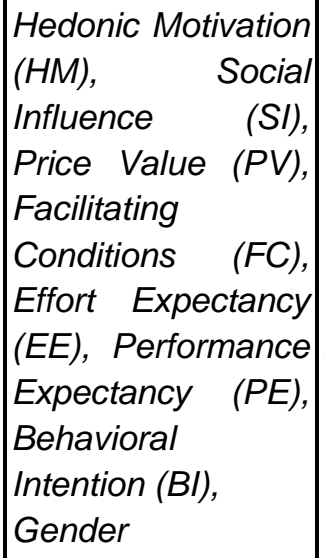 & $\begin{array}{l}\text { Based on research } \\
\text { conducted by HM, SI, PV, } \\
\text { FC, EE, PE has a positive } \\
\text { relationship to BI in using PT } \\
\text { Telkom's home digital service }\end{array}$ \\
\hline
\end{tabular}




\begin{tabular}{|c|c|c|c|c|}
\hline 7 & $\begin{array}{l}\text { Preeti Tak, Savita } \\
\text { Panwar; } 2017\end{array}$ & $\begin{array}{l}\text { Using UTAUT } 2 \\
\text { Model to Predict } \\
\text { Mobile App Based } \\
\text { Shopping: } \\
\text { Evidences from } \\
\text { India[17] }\end{array}$ & $\begin{array}{l}\text { Habit, Hedonic } \\
\text { Motivation (HM), } \\
\text { Facilitating } \\
\text { Conditions (FC), } \\
\text { Social Influences } \\
\text { (SI), Effort } \\
\text { Expectancy (EE), } \\
\text { Behavioral } \\
\text { Intention (BI) }\end{array}$ & $\begin{array}{l}\text { Based on research } \\
\text { conducted by Habit, HM, FC, } \\
\text { SI, EE has a positive effect } \\
\text { on the use of mobile apps }\end{array}$ \\
\hline 8 & $\begin{array}{l}\text { Ali Abdallah Alalwan, } \\
\text { Yogesh K. } \\
\text { Dwivedi, }\end{array}$ & $\begin{array}{l}\text { Factors Influencing } \\
\text { Adoption of Mobile } \\
\text { Banking by } \\
\text { Jordanian } \\
\text { Bank Customer } \\
\text { [18' }\end{array}$ & $\begin{array}{l}\text { Performance } \\
\text { Expectancy (PE), } \\
\text { Effort } \\
\text { Expectancy(EE), } \\
\text { Social } \\
\text { Influence (SI), } \\
\text { Facilitating }\end{array}$ & $\begin{array}{l}\text { PE influences } \mathrm{BI} \text { the most to } \\
\text { use mobile banking. } \\
\text { Furthermore, BI is also } \\
\text { influenced by } \mathrm{EE}, \mathrm{SI} \text {, and FC. }\end{array}$ \\
\hline 9 & $\begin{array}{l}\text { Nripendra P. Rana; } \\
2017\end{array}$ & $\begin{array}{l}\text { Extending UTAUT } \\
2 \text { with Trust [19] }\end{array}$ & $\begin{array}{l}\text { Condition (FC), } \\
\text { Price Value (PV), } \\
\text { Behavioral } \\
\text { Intention (BI), } \\
\text { Hedonic } \\
\text { Motivation (HM), } \\
\text { Trust }\end{array}$ & $\begin{array}{l}\text { HM which is very influential } \\
\text { on the use of mobile banking, } \\
\text { followed by PV. }\end{array}$ \\
\hline 10 & $\begin{array}{l}\text { Adelyn Kuan Lai Kit, } \\
\text { Ann Hui Ni, Emeilee } \\
\text { Nur Freida Binti Mohd } \\
\text { Badri, Tang Kia Yee; } \\
2014\end{array}$ & $\begin{array}{l}\text { UTAUT } 2 \\
\text { Influencing The } \\
\text { Behavioural } \\
\text { Intention to Adopt } \\
\text { Mobile } \\
\text { Applications }\end{array}$ & $\begin{array}{l}\text { Performance } \\
\text { Expectancy (PE), } \\
\text { Effort } \\
\text { Expectancy(EE), } \\
\text { Social Influence } \\
\text { (SI), Facilitating } \\
\text { Condition (FC), } \\
\text { Price Value (PV), } \\
\text { Behavioral } \\
\text { Intention (BI), } \\
\text { Hedonic } \\
\text { Motivation (HM), } \\
\text { Habit }\end{array}$ & $\begin{array}{l}\text { PE, EE, HM and Habit } \\
\text { influence BI to adopt mobile } \\
\text { apps. Meanwhile, SI, FC, and } \\
\text { PV have no effect on BI to } \\
\text { adopt mobile apps. }\end{array}$ \\
\hline
\end{tabular}

Banks are institutions that operate for profit. Article 1 of Law Number 21 of 2008, explains that a bank is an agency that collects funds from the public in the form of savings and is redistributed in the form of credit or other forms. This is done in order to improve the standard of living of many people. In its activities, banks are supervised by a banking supervisory body named by the Financial Services Authority (OJK)[20].

In addition to this understanding, mobile banking is also a banking transaction through mobile media, either in the form of the m-Banking application or the mobile operator's default application. Based on research from the same model of using the UTAUT 2 model conducted by Mas Yogi \& Ariyanto $(2017$, p. 1392) it is explained that interest and behavior towards the use of mobile banking is strongly influenced by the performance expectancy of the 
application[21]. The research suggests mobile banking service providers to guarantee a sense of security for their users by linking the risk factors of using the application.

\section{Result and Discussion}

This research was conducted from December 2019 to January 2020 which was carried out for approximately 1 month. This research was conducted by distributing questionnaires to 96 respondents who are customers of PT Bank Syariah Mandiri Bekasi Branch Office who have activated the Mandiri Syariah Mobile Application and have also used the application. Questionnaires were distributed to customers who came directly to the researchers so that researchers could meet face-to-face with these customers to maintain the validity of the data provided by respondents, as well as assist respondents when difficulties occurred in filling out the questionnaire.

\section{Gender}

In this study, researchers took a sample of 96 respondents. The respondents were divided into 51 respondents were women and 45 respondents were men, the results can be seen in Figure 3 below.

\section{Investigationis Respondent Profile Diagram by Gender}

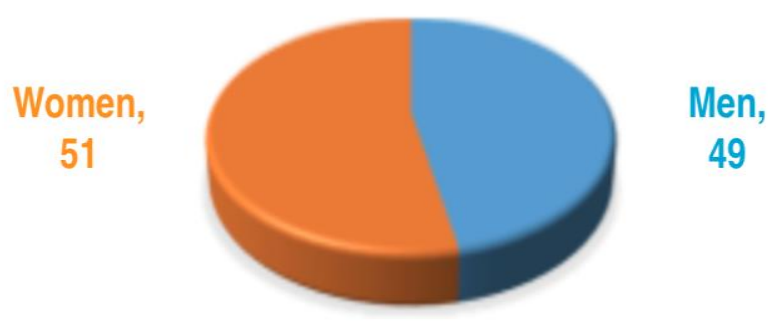

Figure 3. Diagram of Research Respondents Profile Based on Gender

\section{Age}

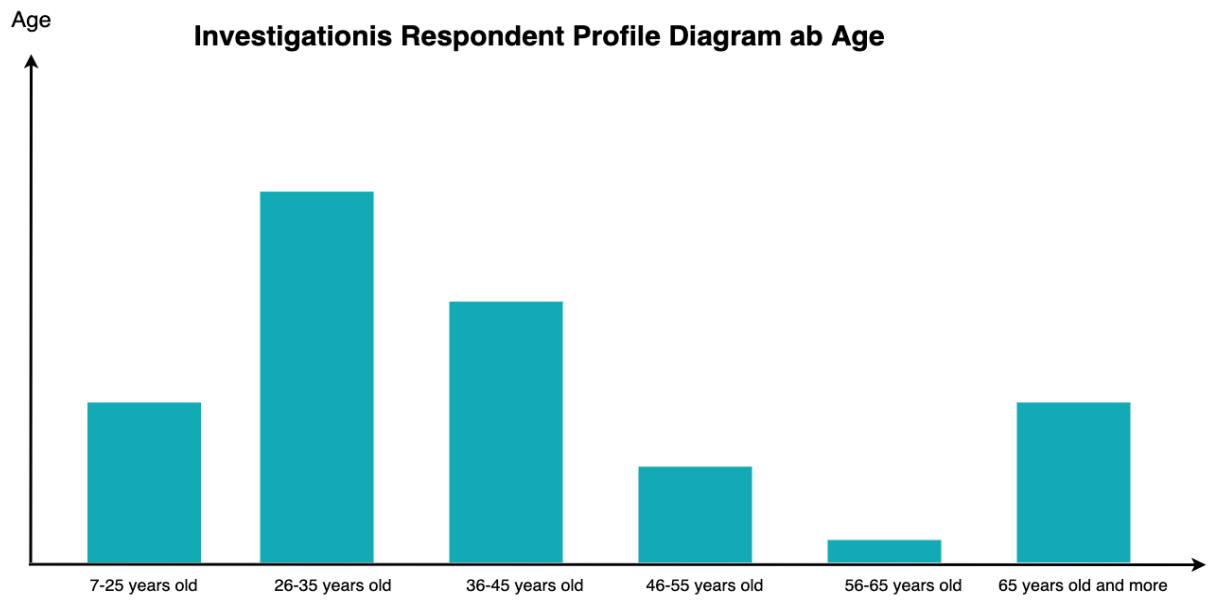

Figure 4 Diagram of Research Respondents Profile Based on Age of Respondents

(Age) 
Based on the picture above, it can be concluded that the age range of 26-35 years is the age group with the highest number of people activating and using the Mandiri Syariah Mobile Application, which is as many as 33 respondents. Development of Unified Theory Acceptance and Use of Technology (UTAUT) 2 Model Several theories that underlie the theory of Venkatesh, et al include:

Theory of Reasoned Action (TRA), Technology Acceptance Model (TAM), Motivation Model (MM), Theory of Planned Behavior (TPB), Combined TAM and TPB, Combined TAM and TPB, Model of PC Utilization (MPCU), Innovation Diffusion Theory (IDT), Social Cognitive Theory (SCT). These theories were reviewed and filtered by Venkatesh, et al for use in researching the acceptance and use of technology. The summary results of the theories carried out by Venkatesh, et al (2003) we now understand as the UTAUT Model.

The UTAUT 2 model can be seen in Figure 5 below.

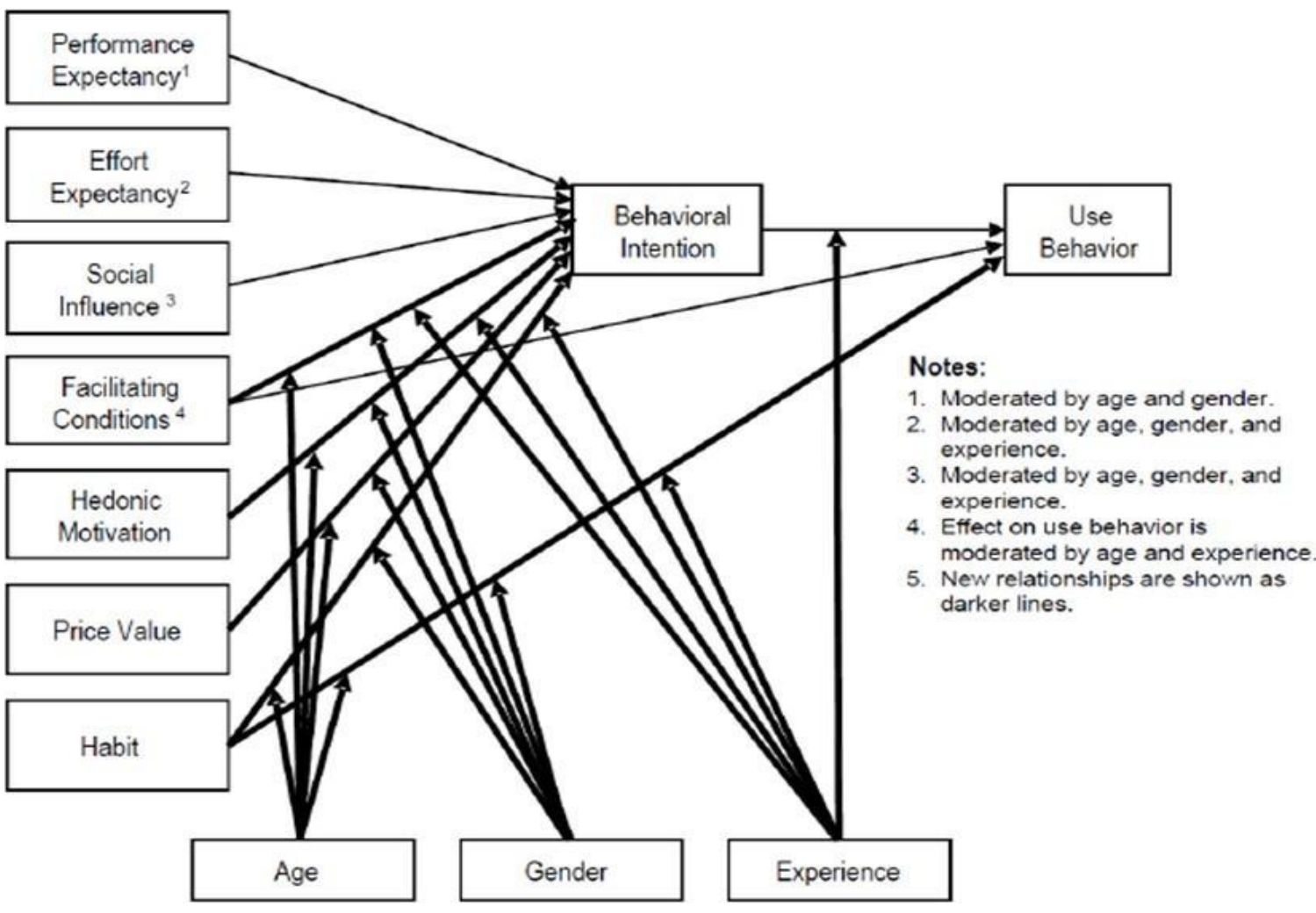

Figure 5. UTAUT 2 Model

Based on Figure 2.01 above, it can be seen that UTAUT 2 has 3 types of variables, namely, independent variables consisting of performance expectancy, effort acceptance, social influence, facilitating conditions, hedonic motivation, price value, and habit; dependent variable which includes behavioral intention and use behavior, as well as moderate variable which consists of age, gender, and experience (Venkatesh, Y. L. Thong, \& Xu, 2012). The description of the addition of 3 (three) constructs, namely: 
1. Hedonic Motivation

2. Price Value

3. Habit

\section{Validity and Reliability Test Results}

Before distributing the questionnaires, the researchers conducted a test distribution of the questionnaires given to 30 respondents. This questionnaire test was conducted to test the validity and reliability of the questions in the questionnaire. A measuring instrument is declared valid if the instrument measures what it is supposed to measure (Sanusi, 2011, p. 76). After the researcher got valid data, then the researcher conducted a reliability test on the question. Umar (2011) explained that the reliability test was used to determine whether the questionnaire instrument could be used more than once at least with the same respondent. The distribution of the research questionnaire test was carried out on December 12, 2019 at PT Bank Syariah Mandiri Bekasi Branch Office. The calculation of the validity and reliability tests was carried out using the IBM SPSS ver 25 program. The results of the two tests can be seen in the table below.

\section{a. Validity Test Results}

The validity test conducted by the researcher was carried out on 25 questions on the independent variable (independent) which was divided into 7 types of variables, and 36 questions on the dependent variable which was divided into 2 types of variables. The results of the validity test can be seen in Table 1 below.

Table 1. Table of Validity Test Results 30 Respondents

\begin{tabular}{|c|c|c|c|}
\hline (Item) & $\begin{array}{c}\mathbf{R} \\
\text { count }\end{array}$ & $\begin{array}{c}\mathbf{R} \text { tabel } \\
\mathbf{5} \% \mathbf{( 3 0 )}\end{array}$ & Criteria \\
\hline PE 1 & 0.826 & 0.361 & Valid \\
\hline PE 2 & 0.931 & 0.361 & Valid \\
\hline PE 3 & 0.965 & 0.361 & Valid \\
\hline PE 4 & 0.743 & 0.361 & Valid \\
\hline EE 1 & 0.868 & 0.361 & Valid \\
\hline EE 2 & 0.903 & 0.361 & Valid \\
\hline EE 3 & 0.958 & 0.361 & Valid \\
\hline EE 4 & 0.929 & 0.361 & Valid \\
\hline
\end{tabular}




\begin{tabular}{|l|l|l|l|}
\hline EE 5 & 0.897 & 0.361 & Valid \\
\hline
\end{tabular}

\begin{tabular}{|c|c|c|c|}
\hline Item & $\begin{array}{c}\text { R } \\
\text { count }\end{array}$ & $\begin{array}{l}\text { R tabel } \\
5 \%(30)\end{array}$ & Criteria \\
\hline SI 1 & 0.848 & 0.361 & Valid \\
\hline $\mathrm{SI} 2$ & 0.876 & 0.361 & Valid \\
\hline $\mathrm{SI} 3$ & 0.870 & 0.361 & Valid \\
\hline FC 1 & 0.754 & 0.361 & Valid \\
\hline $\mathrm{FC} 2$ & 0.913 & 0.361 & Valid \\
\hline FC 3 & 0.944 & 0.361 & Valid \\
\hline FC 4 & 0.768 & 0.361 & Valid \\
\hline $\mathrm{HM} 1$ & 0.801 & 0.361 & Valid \\
\hline $\mathrm{HM} 2$ & 0.928 & 0.361 & Valid \\
\hline HM 3 & 0.874 & 0.361 & Valid \\
\hline PV 1 & 0.800 & 0.361 & Valid \\
\hline PV 2 & 0.925 & 0.361 & Valid \\
\hline PV 3 & 0.952 & 0.361 & Valid \\
\hline $\mathrm{H} 1$ & 0.918 & 0.361 & Valid \\
\hline $\mathrm{H} 2$ & 0.921 & 0.361 & Valid \\
\hline $\mathrm{H} 3$ & 0.874 & 0.361 & Valid \\
\hline $\mathrm{BI} 1$ & 0.796 & 0.361 & Valid \\
\hline $\mathrm{BI} 2$ & 0.909 & 0.361 & Valid \\
\hline $\mathrm{BI} 3$ & 0.831 & 0.361 & Valid \\
\hline U1 & 0.498 & 0.361 & Valid \\
\hline U2 & 0.498 & 0.361 & Valid \\
\hline U3 & 0.528 & 0.361 & Valid \\
\hline U4 & 0.443 & 0.361 & Valid \\
\hline
\end{tabular}




\begin{tabular}{|c|c|c|c|}
\hline U5 & 0.498 & 0.361 & Valid \\
\hline U6 & 0.498 & 0.361 & Valid \\
\hline U7 & 0.443 & 0.361 & Valid \\
\hline U8 & 0.528 & 0.361 & Valid \\
\hline U9 & 0.510 & 0.361 & Valid \\
\hline U10 & 0.521 & 0.361 & Valid \\
\hline U11 & 0.873 & 0.361 & Valid \\
\hline U12 & 0.841 & 0.361 & Valid \\
\hline U13 & 0.848 & 0.361 & Valid \\
\hline U14 & 0.789 & 0.361 & Valid \\
\hline U15 & 0.743 & 0.361 & Valid \\
\hline U16 & 0.838 & 0.361 & Valid \\
\hline U17 & 0.821 & 0.361 & Valid \\
\hline U18 & 0.842 & 0.361 & Valid \\
\hline U19 & 0.873 & 0.361 & Valid \\
\hline U20 & 0.838 & 0.361 & Valid \\
\hline U21 & 0.596 & 0.361 & Valid \\
\hline U22 & 0.498 & 0.361 & Valid \\
\hline U23 & 0.708 & 0.361 & Valid \\
\hline U24 & 0.475 & 0.361 & Valid \\
\hline U25 & 0.527 & 0.361 & Valid \\
\hline
\end{tabular}

\begin{tabular}{|c|c|c|c|}
\hline Item & $\begin{array}{c}\mathbf{R} \\
\text { count }\end{array}$ & $\begin{array}{c}\mathbf{R} \text { tabel } \\
\mathbf{5 \%}(\mathbf{3 0})\end{array}$ & Kriteria \\
\hline U26 & 0.497 & 0.361 & Valid \\
\hline U27 & 0.473 & 0.361 & Valid \\
\hline U28 & 0.712 & 0.361 & Valid \\
\hline
\end{tabular}




\begin{tabular}{|c|c|c|c|}
\hline U29 & 0.528 & 0.361 & Valid \\
\hline U30 & 0.564 & 0.361 & Valid \\
\hline U31 & 0.665 & 0.361 & Valid \\
\hline U32 & 0.478 & 0.361 & Valid \\
\hline U33 & 0.531 & 0.361 & Valid \\
\hline U34 & 0.803 & 0.361 & Valid \\
\hline U35 & 0.536 & 0.361 & Valid \\
\hline U36 & 0.740 & 0.361 & Valid \\
\hline
\end{tabular}

Based on the results listed in table 4.01 above, get an $\mathrm{R}$ Table of 0.361 which is known to be used for the number of $\mathrm{N}=30$ with a significance level of $5 \%$. After performing calculations on the results of the questionnaire test, the researcher calculated from the data that had been obtained to determine Rcount which can be seen in Table 4.01 above. Based on the comparison of Table and Rcount above, it can be concluded that the results of the overall calculation of $R_{\text {count }}>R_{\text {Table }}$ indicate that the entire questionnaire in this study is valid and can be used as an instrument in the study.

\section{b. Reliability Test Results}

The researchers also did the same with the question items to test the reliability of the questionnaire. Reliability test is done by looking for Cronbach's Alpha value. If Cronbach's Alpha value $>0.60$, then the reliability test results are considered reliable (Umar, 2011). The results of the reliability test can be seen in table 2 below.

Table 2. Table of Reliability Test Results 30 Respondents

\begin{tabular}{|c|c|c|c|}
\hline Variabel & $\begin{array}{c}\text { Cronbach's } \\
\text { Alpha Value }\end{array}$ & $\begin{array}{c}\text { Comparison } \\
\text { Results }\end{array}$ & Description \\
\hline $\begin{array}{c}\text { Performance } \\
\text { Expectancy }(\mathrm{X} 1)\end{array}$ & 0.881 & $>0.60$ & Reliable \\
\hline
\end{tabular}

\begin{tabular}{|c|c|c|c|}
\hline Variabel & $\begin{array}{c}\text { Cronbach's } \\
\text { Alpha Value }\end{array}$ & $\begin{array}{c}\text { Comparison } \\
\text { Results }\end{array}$ & Description \\
\hline $\begin{array}{c}\text { Effort Expectancy } \\
(\mathrm{X} 2)\end{array}$ & 0.947 & $>0.60$ & Reliable \\
\hline $\begin{array}{c}\text { Social } \\
\text { Influence }(\mathrm{X} 3)\end{array}$ & 0.830 & $>0.60$ & Reliable \\
\hline $\begin{array}{c}\text { Facilitating Condition } \\
(\mathrm{X} 4)\end{array}$ & 0.860 & $>0.60$ & Reliable \\
\hline
\end{tabular}




\begin{tabular}{|c|c|c|c|}
\hline $\begin{array}{c}\text { Hedonic } \\
\text { Motivation } \\
\text { (X5) }\end{array}$ & 0.826 & $>0.60$ & Reliable \\
\hline $\begin{array}{c}\text { Price Value } \\
\text { (X6) }\end{array}$ & 0.873 & $>0.60$ & Reliable \\
\hline Habit (X7) & 0.888 & $>0.60$ & Reliable \\
\hline $\begin{array}{c}\text { Behavioral } \\
\text { Intention (Y1) }\end{array}$ & 0.781 & $>0.60$ & Reliable \\
\hline $\begin{array}{c}\text { Use Behavior } \\
\text { (Y2) }\end{array}$ & 0.950 & $>0.60$ & Reliable \\
\hline
\end{tabular}

Based on the results of the above calculations carried out to find reliability tests, it can be seen that all variables have a Cronbach Alpha value $>0.60$ which means that the questionnaire is reliable.

\section{Conclusion}

The development of the digital economy that has occurred so far has provided several conveniences, both in conducting business activities, communicating, and even carrying out financial transaction activities. The mobile banking application that is integrated with personal accounts makes various financial needs can be met in just an instant. Customers can perform all financial activities with just the blink of an eye, without having to come to a bank branch office or queue via a teller.

Mandiri Syariah Mobile as one of the mobile banking applications owned by PT Bank Syariah Mandiri is an example of an application that provides many conveniences to its customers. Based on the convenience offered, it turns out that on the ground there are still many customers of PT Bank Syariah Mandiri Bekasi Branch Office who have not actively used the application. Interest in using (behavioral intention) is one of the factors that binds several variables that exist in this study such as performance expectancy, effort expectancy, social influence, hedonic motivation, price value and habit which are factors or determinants of interest in using (behavioral intention). In addition, use behavior is also a determining factor in analyzing interest in using an application.

This study gives the result that age, gender and experience cannot influence the relationship of the seven variables that affect behavioral intention. The results obtained are direct relationships of the seven variables. Performance expectancy ranks first with the greatest influence on its relationship with behavioral intention. Furthermore, the relationship between price value, effort expectancy, habit, social influence, hedonic motivation, and facilitating conditions. The relationship between behavioral intention and Use Behavior has a low relationship which indicates that there is an indirect impact on customer interest in using the Mandiri Syariah Mobile Application based on the relationship between the seven previous variables.

\section{References}

[1] Ranta, V., Aarikka-Stenroos, L., \& Väisänen, J. M. (2021). Digital technologies catalyzing business model innovation for circular economy-Multiple case study. Resources, Conservation and Recycling, 164, 105155. 
[2] Bressanelli, G., Adrodegari, F., Perona, M., \& Saccani, N. (2018). Exploring how usagefocused business models enable circular economy through digital technologies. Sustainability, 10(3), 639 .

[3] Bressanelli, G., Adrodegari, F., Perona, M., \& Saccani, N. (2018). Exploring how usagefocused business models enable circular economy through digital technologies. Sustainability, 10(3), 639.

[4] Maloney, W. F., \& Taskin, T. (2020). Determinants of social distancing and economic activity during COVID-19: A global view. World Bank Policy Research Working Paper, (9242).

[5] Purbasari, A., Maryono, G. P., Mulyanto, F., \& Gusdya, W. (2021). Utilization of Google My Business as a Tourism Promotion Media Using Local Search Engine Optimization. IAIC Transactions on Sustainable Digital Innovation (ITSDI), 2(2), 169-178.

[6] Adiyanto, N. (2021). Customer Relationship Management (CRM) Based On Web To Improve The Performance Of The Company. IAIC Transactions on Sustainable Digital Innovation (ITSDI) The 1st Edition Vol. 1 No. 1 October 2019, 32.

[7] Toimah, T. F., Maulana, Y. I., \& Fajar, I. (2021). Gamification Model Framework and its Use in E-Learning in Higher Education. IAIC Transactions on Sustainable Digital Innovation (ITSDI), 3(1), 28-35.

[8] Nikolopoulou, K., Gialamas, V., \& Lavidas, K. (2020). Acceptance of mobile phone by University students for their studies: An investigation applying UTAUT2 model. Education and Information Technologies, 25(5), 4139-4155.

[9] Ramírez-Correa, P., Rondán-Cataluña, F. J., Arenas-Gaitán, J., \& Martín-Velicia, F. (2019). Analysing the acceptation of online games in mobile devices: An application of UTAUT2. Journal of Retailing and Consumer Services, 50, 85-93.

[10] Tamilmani, K., Rana, N. P., \& Dwivedi, Y. K. (2021). Consumer acceptance and use of information technology: A meta-analytic evaluation of UTAUT2. Information Systems Frontiers, 23(4), 987-1005.

[11] Karanasios, S. (2018). Toward a unified view of technology and activity: The contribution of activity theory to information systems research. Information Technology \& People.

[12] Rahi, S., Ghani, M., Alnaser, F., \& Ngah, A. (2018). Investigating the role of unified theory of acceptance and use of technology (UTAUT) in internet banking adoption context. Management Science Letters, 8(3), 173-186.

[13] Putri, D. A. (2018, May). Analyzing factors influencing continuance intention of e-payment adoption using modified UTAUT 2 model. In 2018 6th International Conference on Information and Communication Technology (IColCT) (pp. 167-173). IEEE.

[14] Gupta, A., Dogra, N., \& George, B. (2018). What determines tourist adoption of smartphone apps? An analysis based on the UTAUT-2 framework. Journal of Hospitality and Tourism Technology. 
[15] Fajar, A. N., Johanes, F. S., Girsang, A. S., \& Wang, G. (2018, September). Evaluation of the used of visual electronic banking system application using UTAUT 2 in Bank Central Asia corporation. In IOP Conference Series: Materials Science and Engineering (Vol. 420, No. 1, p. 012096). IOP Publishing.

[16] Dwivedi, Y. K., Rana, N. P., Tamilmani, K., \& Raman, R. (2020). A meta-analysis based modified unified theory of acceptance and use of technology (meta-UTAUT): a review of emerging literature. Current opinion in psychology, 36, 13-18.

[17] Anggraeni, R., Hapsari, R., \& Muslim, N. A. (2021). Examining Factors Influencing Consumers Intention and Usage of Digital Banking: Evidence from Indonesian Digital Banking Customers. APMBA (Asia Pacific Management and Business Application), 9(3), 193-210.

[18] Gharaibeh, M. K., Arshad, M. R. M., \& Gharaibh, N. K. (2018). Using the UTAUT2 Model to Determine Factors Affecting Adoption of Mobile Banking Services: A Qualitative Approach. International Journal of Interactive Mobile Technologies, 12(4).

[19] Eneizan, B., Mohammed, A. G., Alnoor, A., Alabboodi, A. S., \& Enaizan, O. (2019). Customer acceptance of mobile marketing in Jordan: An extended UTAUT2 model with trust and risk factors. International Journal of Engineering Business Management, 11, 1847979019889484.

[20] Atikah, I. (2020). Consumer Protection And Fintech Companies In Indonesia: Innovations And Challenges Of The Financial Services Authority. Jurnal Hukum dan Peradilan, 9(1), 132153.

[21] Lutfiani, N., Aini, Q., Rahardja, U., Wijayanti, L., Nabila, E. A., \& Ali, M. I. (2021). Transformation of blockchain and opportunities for education 4.0. International Journal of Education and Learning, 3(3), 222-231. 